\title{
ASSESSMENT OF THE PROBLEMS IN THE MANAGEMENT OF URBAN HOUSING (A CASE STUDY OF OWERRI MUNICIPALITY, IMO STATE)
}

\author{
Nwabueze, O.p.O ${ }^{1}$., Onwuka, E.O. ${ }^{2}$, Uzomba, N.I ${ }^{3}$, Ekeh, C.U.N ${ }^{4}$. \\ Akuesi, C.U $\mathbf{U}^{5}$. \\ ${ }^{I}$ Department of Urban and Regional Planning \\ ${ }^{2}$ Department Building Technology \\ ${ }^{3}$ Department of Microbiology/Biochemistry \\ ${ }^{4}$ Department of Estate Management \\ ${ }^{5}$ Department of Environmental Microbiology \\ Federal Polytechnic Nekede, Owerri, Imo State
}

Corresponding Authors: Uzomba, N.I

Article DOI: https://doi.org/10.36713/epra7310

DOI No: 10.36713/epra7310

\begin{abstract}
The high rate of migration, coupled with population increase triggered rapid urbanization. However, a great proportion of the population still lives in substandard and low quality houses in a deplorable unsanitary residential environment particularly in developing countries. Urban and Economic growth have brought about all typical problems associated with rapid urban development resulting in housing shortage both quantitative and qualitative, slums, illegal settlement and squatting as experienced in owerri municipality. These have resulted into many urban and housing problems within the state capital owerri. This study examined the nature of urban growth and housing problems in owerri municipality. Also it tries to examine residential housing stock, identity the nature of housing problems, government policies and programmes in other to address the problems. The pattern of growth was determined using spatial analysis, and the housing problems were identified through questionnaire and field surveys. Findings revealed that the growth of urban housing in owerri municipality increases by 1034.0 hectare which is equivalent to $38.5 \%$ which is in line with Maurice (2004). It was also discovered that over a period of time, new settlements have evolved. Also, the construction and expansion of road networks are evidences of urban growth in owerri municipality.
\end{abstract}

KEYWORDS: Development, Urban growth, Housing problems, population, owerri municipality.

\section{INTRODUCTION}

This is a study of an assessment of management of housing problem in urban areas of Nigeria using Owerri municipality council as a case study. Housinggenerally has not been ranked high on the scale of priorities for social expenditure and state governments have been relying upon local council authorities to meet up with the challenges faced by urban dwellers. Efforts aimed at developing low-cost urban housing have been minimal despite the creation of the federal mortgage Bank of Nigeria in 1977 to alleviate the problems of housing in urban areas. Overcrowding 


\section{SJIF Impact Factor 2021: 8.013| ISI I.F.Value:1.241| Journal DOI: 10.36713/epra2016 ISSN: 2455-7838(Online) EPRA International Journal of Research and Development (IJRD) \\ Volume: 6 | Issue: 6 | June 2021 \\ - Peer Reviewed Journal}

has been a problem in these areas and it has been estimated that about $85 \%$ of the urbanpopulation live in single rooms, often with six to eight persons per room. In 1996, only about $27 \%$ of urban dwellers had access to portable water supply and less than $10 \%$ of urban dwellers have an indoor toilet. As of 1979, about 3720 of all housing units were cement or brick roofed with asbestos or corrugated iron, $34 \%$ were mud plastered with cement and roofed with corrugated iron. In the same vein, $44 \%$ of urban dwellers were rented, $37 \%$ were owner occupied, $17 \%$ wererent free and $2 \%$ were "quasirented" at below-average rates and the total number of housing units in 1992 was 25, 661, 000 (National housing policy, 2011).

The revised draft for the national housing policy, (2011), defines housing as the process of simultaneous production (building to target prices of large number of decent, safe sanitary and affordable residential building with recurs tenure on a continuous and prevalent basis with adequate physical infrastructure, amenities and social services in a planning healthy and livable environment to meet the basic and special needs of the population and reflecting their social economic cultural aspirations and references. In Nigeria, problems in the management of urban housing are enormous and complex, showing apparent and marked regional differences in most urban centres is not only restricted to the quality of housing stock but also to the quantity of available housing units infrastructure and the environment. The result is manifested in growing overcrowding in houses, neighborhoods, communities and increasing pressure on infrastructural facilities such as roads drainages, power supply and rapidly deteriorating environment. The provision of housing in a giving area may be linked with specific policies which include the free market approach where people are expected to participate in the building of houses for themselves as well as the government embarking on construction of housing estates at subsidized rate. The study area Owerri municipality has a mixed population, predominantly civil servants, with increasing administrative, commercial and industrial activities. People from all walks of life are attracted to the area resulting to high population density. The establishment of federal tertiary institutions in owerri such as Federal University of Technology Owerri (FUTO), Alvan Ikoku Federal College of Education Owerri, Federal Collage of lands Resources and Technology Oforola, Owerri, and State Owned tertiary Institutions close to the center of the town have added to the population as well as increase in the demand for residential accommodation, offices and shops.

\section{AIM}

The paper is an attempt at accessing the problems of the management of urban housing in Owerri municipality in order to solve the urban housing problems of the inhabitants of the city, mostly Civil servants whose income are not enough to build their own houses.

\section{OBJECTIVES}

1. To examine the nature of housing problems in Owerri municipality.

2. To identity the causes of the problems associated with residential housing in Owerri.

3. To examine possible solution at solving these problems.

4. To examine the existing policies in Nigeria towards solving the housing problems.

\section{RESEARCH QUESTIONS}

1. Characteristics of housing problems in Owerri Municipality.

2. Income levels of the respondents.

3. Occupational status of the respondents.

4. Respondents refuse dump site.

5. Age status of the respondents.

\section{HYPOTHESES}

1. There is no significant relationship between characteristics of the houses and problems of the urban housing.

2. There is no significant relationship between refuse dump site and problems of urban housing.

\section{LITERATURE}

Housing is one of the three basic needs of mankind and it is the most important for the physical survival of man after the provision of food. Adequate housing contribute to the attainment of physical and mental health of a 


\section{SJIF Impact Factor 2021: 8.013| ISI I.F.Value:1.241| Journal DOI: 10.36713/epra2016 ISSN: 2455-7838(Online) EPRA International Journal of Research and Development (IJRD) \\ Volume: 6 | Issue: 6 | June 2021 \\ - Peer Reviewed Journal}

nation and stimulates the social stability, work efficiency and development of the individuals. The Nigeria housing policies and programmes are in crises situation, manifesting and expressing itself in quantitative and qualitative forms there is lack of comfort and rudimentary infrastructure, congestion, unhygienic environment, high density population in or surrounding occurs in our urban centers. The spatial product of these problems is not only in the emergence and deployment of slums and squatters of various forms but in the proliferation of suburbs (Abiodun, 1998)

\section{A. ECONOMIC GROWTH AND URBANIZATION IN NIGERIA}

Economic growth is one of the important determinants of urbanizationin any country of the world. It emphasizes equitable distribution of goods and services, provision of employment opportunity and other services needed by human (Oberai, 1992).

The level of Urbanization of any country refers to percentage of the total population of the country that lives in the towns and cities therefore urbanization expresses the growth of towns at the expense of the rural areas. It is a measure of the shift of population from one end to another side (Maurice, 2004). The four major determinants of urbanization includes,

(i) Economic growth and development

(ii) Rural-urban Migration

(iii) Technology change

(iv) Rapid growth in population in developing nations like Nigeria.

Urbanization parameters progresses at a phenomenal rate without any articulated policies to stem its tide. The dynamics of this processes reviews that less than $15 \%$ of the population lived in cities of 20,000 or more population by 1950 , and in $\mathrm{n} 1975$, this proportion increase to $23.4 \%$ and by the year 2025 , the proportion has risen to $13.3 \%$. It is said that in 2025, more than half of the country's population will live in urban centers (Mabogunje, 2003).

\section{B. NIGERIAN'S HOUSING PROBLEM}

Many renowned scholars as well as distinguished regional and international organization concerned with urbanization and housing at global levels have long expressed immense anxieties over the alarming nature and dimensions of the housing problems in the nations of the developing world like Nigeria, Brazil, and Egypt. This crises situation in urban housing in this integrated forms has surpassed the terrenes of the social; sphere, reproducing itself in the economic political and environmental processes of these nations of the third world countries (I.A.H.S., 2005).

In Nigeria mist people live in poor quality housing and in unsanitary environments. The problems of inequality housing have been compounded by the rapid rates of urbanization and economic growth. Housing difficulties is more serious for the low income groups where problems have been complicated by rapid growth, inflated real estate values, speculative activities and influx of poor immigrants and lack of planning. Some of the factor responsible for shortage of housing in Nigeria includes

\section{National Economy}

The economic situation of the country which is the bases of any country has passed through many stages. The rapid increase in prices of petroleum products in 1980's that follows the period of boom result in a near collapse of the economy today due to total dependent on the petroleum oil (Anugwom, 19995). Devaluation of Nigerians currency has made importation of building materials a difficult one.

The cost of acquisition of land and building a residential accommodation have gone up that some investors feel that it is risky investing in the housing sector and this means that new houses are not forthcoming to augument the already existing stock of houses (Austin, 1991). Also increase in population of our cities as a result of rural-urban migration for greener pastures by our youths, school leavers graduates, business men without a corresponding increase in the provision of housing is a major factor urban housing problems. (Okeke, 1983).

\section{Land tenure}

One of the important problems of housing is land. The fragmentation of the land and heterogeneous nature of our communities which has various ethnic groups that has land tenure arrangement distinguished from those of others, even the land decree of 1928 could not resolve the problem completely. The land tenure system leads to enormous problems in acquiring land for housing (Igbozuruike 1981) 


\section{SJIF Impact Factor 2021: 8.013| ISI I.F.Value:1.241| Journal DOI: 10.36713/epra2016 ISSN: 2455-7838(Online) EPRA International Journal of Research and Development (IJRD) \\ Volume: 6 | Issue: 6 | June 2021 \\ - Peer Reviewed Journal}

\section{Cost of land acquisition}

The acquisition of land in our urban areas is very expensive and has made affordable by only the rich in the society. The middle class and others are forced to move to the outskirts of the cities. The high cost of land brings about stockings of land thereby reaching the number of housing units (Maurice, 2004)

\section{High cost of building materials}

The cost of building materials in our markets are high and this has contributed in a great measure in reducing the housing units in our urban areas. Mabogunje, (2003) observed that with the rate in increase in building materials, construction of new buildings would be a herculean task. People's intention of erecting new structures for residential purposes are discouraged by the cost of building materials thereby making the plans unrealizable and the problem of housing estate lingers.

\section{Increase in rent}

The construction of building involves huge capital. A high risk interest rates and inflationary trend in the economy have affected activities in the housing sector adversely. An investor in the housing stock finds it difficult to secure credit from financial institution. This is because high interest means high cost of fund which implies that the supply end of the housing sector will be stagnant. Households, therefore are made to pay high rent which encroaches very much into their income (Adeniyi, 1981).

\section{PROBLEMS OF PROPERTY DEVELOPMENT}

Development is defined under section 22 of town and country planning Act 1991(British) as the carrying out of building engineering, mining or other operations in, on, over or under land, or making of any materials change in the use of any building or land. Property development in Nigeria faced with a lot of problems which has affected it seriously includes,

\section{Lack of fund}

Igbozuruike (1981), observed that fund is the backbone of any forum of development. To end this, projects requiring huge sum of money cannot effectively be financed by private bodies which most of the time are not completed due to lack of funds and as a result, property development suffers. This implies that only public authorities embark on big property development projects.

\section{Acquisition of land}

Developers are faced with the problems of acquiring land for developmental purposes. According to Jude (2012), the land use Act of 1978 caused more problems than it can solve. Individuals holding of land in small portions has continued to pose a very big problems. Even if the land is acquired, provision of alternative accommodation, rehousing or disposed occupiers and payment of compensation is not an easy task.

\section{Unavailability of credit facilities}

Okeke,(1983), observed that financial institutions are the bedrock of anti-capital intensive development. Based on facts above, unavailability of credit facilities like loan, overdraft and high interest rates on the borrowed money has discouraged a lot of developers, thereby making property development suffer.

\section{Political instability}

Changes in political leadership over time has contributed a lot in the problem of housing development. Each administration comes up with its developmental plans, leaving behind the already existing plan lain down by its predecessors and embarking on a new project. This action always results in uncompleted projects, waste of resources and time (sada, 1990)

\section{Technology and labour}

According to Abiodun, (1998), the level of development in any country is greatly determined by its available technology and workforce. The type of technology required for certain development and re-development are lacking in our country. New innovations and changes in design are not yet obtainable in the country. The required manpower for specific jobs is lacking and one do not have enough skilled and semi-skilled labour that has the needed skill to supervise some developmental projects.

\section{ECONOMIC AND SOCIAL BACKGROUND OF OWERRI}

Owerri was an administrative centre of government in early 1960's. Presently, it is the administrative capital of Imo state of Nigeria. It houses the seat of government and other ministries in the state. There are presence of 


\section{SJIF Impact Factor 2021: 8.013| ISI I.F.Value:1.241| Journal DOI: 10.36713/epra2016 ISSN: 2455-7838(Online) EPRA International Journal of Research and Development (IJRD) \\ Volume: 6 | Issue: 6 | June 2021 \\ - Peer Reviewed Journal}

serious commercial activities going on in the area. Stores are located in the area mainly used by traders for the sales of some of their goods like electrical appliances, pharmaceuticals, food items. In the 1960's people embarked on the building of bungalow, tenace houses and tenement buildings but since the creation of Imo state in 1976 and Owerri was named the state capital, there has evolutions of flats, duplexes, estates etc. This has resulted to the increase in house rents and demand for houses as a result of over population of the city center. Owerri have mixtures of great number of low income earners, medium income group and few privileged high income group. The flats and duplexes cannot be affordable by the low and medium income earners resulting in a high rush for tenement building most of which are deteriorated and obsolete, thereby causing over usage of existing facilities present in these building.

\section{SOCIAL BACKGROUND}

Owerri is composed of some societal infrastructure which includes road networks that lures it with other major cities in the country. There is the provision of medical services owned by the government and private ones. The cities houses almost all the federal and stateinstitutions of higher learning. Other social amenities like pipe borne water supply from the water board, star hotels located in every nook and crannies of the city, recreational facilities and business centres found in the city. With the position Owerri, commercial activities, private companies and government ministries has contributed to the increase in the population of the area and resultingto the social ills and violence experienced in the city center. Irrespective of the presence of the military and police with their stations situated within the urban center, the crime rate and violence continues to increase

\section{RESEARCH METHODOLOGY \\ METHOD \\ Description of Study Area}

Owerri is the capital city of Imo State and from National Population Commission (2013), Owerri municipality and its environs has a total population of 220,660 residence. This population comprises of civil servants, businessmen and the other professionals who occupied over 10,000 residential buildings

\section{STUDY POPULATION}

Eligible occupants of the municipality of 120 people used for this study were drawn from different locations of the municipality. The questionnaires contains 25 questions which centres mainly on the problem of urban housing encountered by the residents of the municipality

\section{RESEARCH DESIGN}

Data used for this study were collected from primary and secondary sources. This operation was useful to determine the event of the growth of Owerri municipality area over the period of study. Questionnaire and field survey were employed to identify the housing problems in the municipality. Secondary data were sourced from published works and owerri municipal council. Other sources of information includes; personal observations, interviews with private developers and traders of building materials as well as government officials. A record of the existing public and private housing stock was used to determine the extent of residential development in the municipality. A reconnaissance and the land use survey of the area carried out to update the existing structures in the area of study

\section{DATA ANALYSIS METHOD AND STATISTICAL TOOLS USED}

1. The research was presented and analysis of the data was done using frequency distribution and sample percentages; while Chi-square $\left(\mathrm{x}^{2}\right)$ was used to test hypothesis. 


\section{FINDINGS AND DISCUSSION}

Table 1: Age status of the respondents

\begin{tabular}{|c|c|c|}
\hline Age (years) & Frequency & Percentage (\%) \\
\hline $0-15$ & 0 & 0.0 \\
\hline $16-30$ & 44 & 36.7 \\
\hline $31-45$ & 64 & 53.3 \\
\hline $46-60$ & 12 & 10.0 \\
\hline 61 and above & 0 & 0.0 \\
\hline Total & 120 & 100 \\
\hline
\end{tabular}

About $53.3 \%$ and $36.7 \%$ of the respondents respectively of the belongs to $31-45$ and $16-30$ age groups which indicates that the respondents can provide important information on the subject of study. The finding showed that $62 \%$ of the respondent's males and 38\% female in which $45 \%$ are married and expected to bear children which are an indication that there is the tendency of population growth in this area in the nearest future.

Table 2 occupational status of respondents

\begin{tabular}{|c|c|c|}
\hline Occupation & Frequency & Percentage (\%) \\
\hline Civil servants & 47 & 39.2 \\
\hline Farmers & 7 & 5.8 \\
\hline Traders & 14 & 11.7 \\
\hline Self employed & 16 & 13.3 \\
\hline unemployed & 36 & 30.0 \\
\hline
\end{tabular}

Occupation is an important socio economic variable as it is used to determine the standard of living of the respondents. The table 2 above shows that the majority of the respondent with $39.2 \%$ are civil servants while about $13.3 \%$ are self-employed, $11.7 \%$ are traders and about $5.8 \%$ are farmers. It is a very big problem that $30.0 \%$ of the population are unemployed and cannot cater for their housing needs and other necessary demands as most of them who are unemployed engages themselves in miscellaneous and odd jobs in the area which have no steady income.

Table 3: Income level of Respondents

\begin{tabular}{|l|c|c|}
\hline \multicolumn{1}{|c|}{ Income in Naira per Month } & Frequency & Percentage (\%) \\
\hline $0-10,000$ & 66 & 55 \\
\hline $11,000-20,000$ & 18 & 15 \\
\hline $21,000-30,000$ & 21 & 17.5 \\
\hline 30,000 and above & 15 & 12.5 \\
\hline & 120 & 100 \\
\hline
\end{tabular}

The above table 3 shows a large percentage of the respondents comprises of 55\% earn 0- 110,000 monthly or per month. The monthly income of $17.5 \%$ of the respondents ranges from $21,000-30,000$ while that of $\$ 11,000-\$ 20$, 000 and $\$ 30,000$ and above are $15 \%$ and $12.5 \%$ respectively. The level of income is a determining factor of the type of house one occupies and once income always determine what he can afford for the rent. High income earners in most cases would prefer to live in more descent houses unlike low income earners who cannot afford such package. They would rather go for a less quality and cheaper houses which their income can afford. 
Table 4: Respondents refuse dump sites

\begin{tabular}{|l|c|c|}
\hline \multicolumn{1}{|c|}{ Site } & frequency & Percentage (\%) \\
\hline Unauthorized place & 35 & 29.2 \\
\hline Private ownership & 49 & 40.8 \\
\hline Government Allocated place & 36 & 30.0 \\
\hline Total & 120 & 100 \\
\hline
\end{tabular}

Waste management is one of the most important urban growth issues which must be handled appropriately to avoid some other environmental problems. If waste is not properly disposed, it blocks water channels which could lead to flooding and environmental pollution. It can be seen from table 4 above that $40.8 \%$ of the respondent dispose their refuse privately, while about $30 \%$ dispose theirs in government dump sites and $29.2 \%$ of the respondent dump their refuse indiscriminately in unauthorized places is a matter of serious concern. This can be connected with the fact that the condition of urban infrastructure in most of Nigeria cities is unsatisfactory because most urban environments are characterized by poor drainage and sewage system, uncollected garbage from industrial, commercial and domestic establishments.

Table 5: Characteristics Housing problem in Owerri Municipality

\begin{tabular}{|l|c|c|}
\hline \multicolumn{1}{|c|}{ Housing Problem } & Frequency & Percentage (\%) \\
\hline Over population & 17 & 14. \\
\hline Poor ventilation & 13 & 10.8 \\
\hline High cost of rent & 23 & 19.2 \\
\hline Over population and high cost of rent & 18 & 15 \\
\hline $\begin{array}{l}\text { Over population, high cost of rent and poor } \\
\text { ventilation }\end{array}$ & 28 & 23.3 \\
\hline Poor ventilation and high cost of rent & 21 & 17.7 \\
\hline Total & 120 & 100 \\
\hline
\end{tabular}

From the survey conducted it was observed that some of the respondents are living in rented houses that are usually overcrowded with poor sanitation which leads to ill-health, because environment has great and obvious effects on human health, comfort and wellbeing. As a result of high cost of rent in the area, many more people occupy a single rooms to share the rent in some cases. Consequently, the exact high pressure on the available housing facilities in the area. This is in agreement with the finding of Mabogunje et al (1978), who observed that lack of adequate housing in Nigeria is one of the factors responsible for large proportion of the urban population living in high density housing unit, in spite of the environmental conditions which contribute serious threat to human health and their productivity. More so, the influx of people into Owerri, the high cost of urban land and building materials are the reasons for more people living in rented house in the area.

\section{TEST FOR HYPOTHESIS}

In testing the hypothesis, Chi square $\left(\mathrm{x}^{2}\right)$ was used at $5 \%$ or 0.05 level of significance.

$$
\mathrm{X}^{2}=\frac{\Sigma(0-\mathrm{E})^{2}}{\mathrm{E}} \text { at } \mathrm{df}_{0.05}(\mathrm{~m}-1)(\mathrm{n}-1)
$$

Where $\mathrm{O}=$ Observed frequency

$\mathrm{E}=$ expected frequency

$\mathrm{DF}=$ Degree of freedom

$\mathrm{m}=$ Number of rows 


$$
\begin{aligned}
& \mathrm{n}=\text { Number of columns } \\
& \mathrm{Ho}=\text { Null Hypothesis } \\
& \mathrm{Ha}=\text { Alternative Hypothesis }
\end{aligned}
$$

Accept Ho if $X^{2} \mathrm{cal} \leq \mathrm{X}^{2}$, at a level of significance, otherwise reject Ho.

\section{Hypothesis One}

Ho: There is no significant relationship between characteristics of the houses and problems of urban housing.

$\mathbf{H}_{\mathbf{A}}$ : There is significant relationship between characteristics of the houses and problems of urban housing. Test Statistics $\mathrm{X}^{2}=\frac{\Sigma(0-\mathrm{E})^{2}}{\mathrm{E}}$

This relationship was tested based on table 5 .

Table 6: Table of Observed and Expected frequency for Hypothesis one (A)

\begin{tabular}{|l|c|c|c|c|}
\hline Housing Problem & YES & NO & Frequency & Percentage (\%) \\
\hline Over population & 14 & 3 & 17 & 14. \\
\hline Poor ventilation & 11 & 2 & 13 & 10.8 \\
\hline High cost of rent & 18 & 5 & 23 & 19.2 \\
\hline Over population and high cost of rent & 10 & 8 & 18 & 15 \\
\hline $\begin{array}{l}\text { Over population, high cost of rent and } \\
\text { poor ventilation }\end{array}$ & 21 & 7 & 28 & 23.3 \\
\hline Poor ventilation and high cost of rent & 14 & 7 & 21 & 17.7 \\
\hline Total & 88 & 32 & 120 & 100 \\
\hline
\end{tabular}

Table 6: Table of Observed and Expected frequency for Hypothesis one (B)

\begin{tabular}{|c|c|c|c|}
\hline $\mathbf{O i}_{\mathbf{J}}$ & $\mathbf{E i}_{\mathbf{J}}$ & $\mathbf{O} i_{\mathbf{J}} \mathbf{-} \mathbf{E i}_{\mathbf{J}}$ & $\boldsymbol{\Sigma}\left(\mathbf{O} \mathbf{i}_{\mathbf{J}} \mathbf{-}-\mathbf{E i}_{\mathbf{J}} \mathbf{)} \mathbf{2} \mathbf{E i}_{\mathbf{J}}\right.$ \\
\hline 14 & 10.3 & 3.7 & 1.33 \\
\hline 3 & 0.8 & 2.2 & 6.05 \\
\hline 11 & 8.1 & 2.9 & 1.05 \\
\hline 2 & 0.5 & 1.5 & 4.50 \\
\hline 18 & 13.2 & 4.8 & 1.75 \\
\hline 5 & 1.3 & 3.7 & 10.53 \\
\hline 10 & 7.3 & 2.7 & 1.00 \\
\hline 8 & 2.1 & 5.9 & 16.58 \\
\hline 21 & 15.4 & 5.6 & 2.04 \\
\hline 7 & 1.9 & 5.1 & 13.69 \\
\hline 14 & 10.3 & 3.7 & 1.33 \\
\hline 7 & 2.2 & 4.8 & 10.47 \\
\hline & & Total & $\mathbf{7 0 . 3 1}$ \\
\hline
\end{tabular}

$\mathrm{X}^{2} \mathrm{cal}=70.31, \mathrm{X}^{2} \mathrm{tab}(0.05)_{5}=11.07 \quad \mathrm{X}^{2} \mathrm{tab}=(\mathrm{M}-1)(\mathrm{N}-1) \quad \mathrm{X}^{2}$ tab $=(6-1)(2-1) \mathrm{X}^{2} \mathrm{tab}=(0.05)_{5}$ Decision: since $X^{2} \mathrm{cal}=\mathrm{X}^{2}$ tab that is $70.31 \geq 11.07$

We reject the Ho (Null hypothesis) and accept $\mathrm{H}_{\mathrm{A}}$ (Alternative hypothesis) and conclude that there is a significant relationship between characteristics of housing and problems of urban housing.

\section{HYPOTHESIS TWO}

Ho There is no significant relationship between refuse dump sites and problems of urban housing. 
$\mathrm{H}_{\mathrm{A}}$ there is significant relationship between refuse dump site and problems of urban housing

$$
\text { Test Statistics } \mathrm{X}^{2}=\frac{\sum(0-\mathrm{E})^{2}}{\mathrm{E}}
$$

This relationship was tested based on table 4 .

Table 7: Table of Observed and Expected frequency for Hypothesis two (A)

\begin{tabular}{|l|c|c|c|c|}
\hline Site & Yes & No & frequency & Percentage (\%) \\
\hline Unauthorized place & 20 & 15 & 35 & 29.2 \\
\hline Private ownership & 30 & 19 & 49 & 40.8 \\
\hline Government Allocated place & 20 & 16 & 36 & 30.0 \\
\hline Total & 70 & 50 & 120 & 100 \\
\hline
\end{tabular}

Table of Observed and Expected frequency for Hypothesis two (B)

\begin{tabular}{|c|c|c|c|}
\hline $\mathbf{O} \mathbf{i}_{\mathbf{J}}$ & $\mathbf{E} i_{\mathbf{J}}$ & $\mathbf{O i}_{\mathbf{J}}-\mathbf{E i}_{\mathbf{J}}$ & $\mathbf{\Sigma}\left(\mathbf{O} \mathbf{i}_{\mathbf{J}}-\mathbf{E i}_{\mathbf{J}} \mathbf{)} \mathbf{2} \mathbf{\mathbf { E }} \mathbf{i}_{\mathbf{J}}\right.$ \\
\hline 20 & 11.7 & 8.3 & 5.89 \\
\hline 15 & 6.3 & 8.7 & 12.01 \\
\hline 30 & 17.5 & 12.5 & 8.93 \\
\hline 19 & 7.9 & 11.1 & 15.60 \\
\hline 20 & 17.5 & 2.5 & 0.36 \\
\hline 16 & 6.7 & 9.3 & 12.91 \\
\hline
\end{tabular}

$\mathrm{X}^{2} \mathrm{cal}=55.7, \mathrm{X}^{2} \mathrm{tab}(0.05)_{2}=5.99 \mathrm{X}^{2} \mathrm{tab}=(\mathrm{M}-1)(\mathrm{N}-1) \quad \mathrm{X}^{2} \mathrm{tab}=(3-1)(2-1) \mathrm{X}^{2} \mathrm{tab}=(0.05)_{2}$

Decision: since $\mathrm{X}^{2} \mathrm{cal}=\mathrm{X}^{2}$ tab that is $55.7 \geq 5.99$

We reject the Ho (Null hypothesis) and accept $\mathrm{H}_{\mathrm{A}}$ (Alternative hypothesis) and conclude that there is a significant relationship between refuse dumpsite and problems of urban housing.

\section{CONCLUSION AND RECOMMENDATION Conclusion}

The high rate of migration, coupled with population increase triggered rapid urbanization in Owerri municipality in Imo State. This has resulted into many urban and housing problems with in the municipality. This study examined the nature of urban growth and housing problems in Owerri municipality. The pattern of growth was determined using spatial analysis, and the housing problems were identified by the use of questionnaires and field surveys. Findings revealed that the area of Owerri municipality increases by 1034.0 hectare which is equivalent to $38.5 \%$ which is in line with Maurice, (2004), and will increase more as the years goes on. It was discovered that new settlement have evolved over the period. The Owerri city has spread towards Okigwe road, MCC/Uratta road down to Toronto Avenue and Egbu axis. Also, there was increasing spread of development towards Avu, Obinze, Oforola, World Bank, Umuguma axis all along Owerri-portharcourt express road. The increasing population witnessed along Nekede, Ihiagwa, Agbala, Ulakwu and its environ are evidence of urban growth in the Owerri city. The emergency of new settlement at Amakohia/Akwakuma, Ubomiri, Ohi, Irete, Orogwe and Ogbaku with the Capital city are another evidence of urban growth. It was also observed that the current expansion has changed the settlement pattern of Owerri municipality in these areas from radial to irregular pattern. Although, there are mixed feelings among the respondents that overpopulation, high cost of rent and poor ventilation are some of the major urban growth and housing problems in the municipality area. These can be attributed to the fact that housing demand exceeds the housing supply in the area as established by government officials, developers and other stakeholders in the area. Other problems include overcrowding, dirty toilet, poor sanitation, inadequate water supply, irregular electricity supply, and ill-health. It should be noted that housing problems cannot be separated from urban growth but the nature of the problems depends on the pattern of growth which varies from one geographical location to another. 


\section{SJIF Impact Factor 2021: 8.013| ISI I.F.Value:1.241| Journal DOI: 10.36713/epra2016 ISSN: 2455-7838(Online) EPRA International Journal of Research and Development (IJRD) \\ Volume: 6 | Issue: 6 | June 2021 \\ - Peer Reviewed Journal}

\section{Recommendations}

Based on the finding of this study, the following recommendations are made:

1. Government should build low-cost housing estates in the municipality in order to provide good and adequate housing units spread in these new settlement areas. This can be achieved through public private partnership. Low-cost houses can be giving to civil servants in the municipality through housing loan scheme in order to help them own their houses.

2. Commercial and mortgage banks should help in provision of loans for housing to the general public as it will help in increasing the number of people who own houses.

3. The ministry of Housing and Urban Development should address the high cost of rent in the area through appropriate legislations.

4. Government should control all developments within Owerri municipality to avoid current irregular growth pattern, overcrowding and poor ventilation as experienced in the area. There is also the need to review the master plan of the Owerri municipality by Owerri Capital Development Authority (O.C.D.A.) to cater for the current and future changes in the area.

FUNDING: This research work was funded by Nigeria Tertiary Education Trust (TETfund) through Institution Base Research (IBR) Project Grant 2020. (TETfund/DR\&D/CE/POLY/NEKEDE/2020/RP/VOL. 1)

\section{ACKNOWLEDGEMENTS}

The authors would like to acknowledge TETFund for their financial support and management of The Federal Polytechnic Nekede, Owerri for providing research facilities.

\section{REFRENCES}

1. Abiodun, J.O. (1998). Environmental poverty and sustainable development in Nigeria cities; Nigeria social scientist Vol. 1 (1) No 4 pp 10

2. Abiodun, Y. (1998). Urban development lessons from Brazil. The punch newspaper, Nov. 5.

3. Abiodun, J.O. (1998). Environmental poverty and sustainable development in Nigeria cities; Nigeria social scientist Vol. 1 No. 1.

4. Adeniyi, E.O. (1981). Housing the urban masses in Nigeria. Nigeria Journal of development Studies, vol. 1, No. 2 pp 5.

5. Austin, C.O. (1991). "Housing situation in a developing and distressed economy Nigeria".

6. Bada, P.O. (1990). Political policies and the development of transportation in metropolitan Lagos, Nigeria geographical Journal, Vol. 13, No. 6.

7. Federal Ministry of Lands, Housing and Rural Development: National Housing and Rural Development policies (2011).

8. Federal Ministry of National Planning: Nigeria vision 2000-2021. First National implementation plan volume 1 and 2 (2011-2013).

9. Igbozuruike, U.M. (1981). Land use and conservation in Nigeria, University of Nigeria press.

10. Jude Ojokwu (2012). An overview of public housing delivery strategies in Nigeria. Journal of environmental biology and valuation volume 1 No. 12012.

11. Mabogunje, A.L. (2002.) Towards an urban policy in Nigeria. Nigerian Journal of economic and social studies, 16(1): 85-87.

12. Mabogunje, A.L. (2003). Welcome address at the stakeholder's forum on strategies for enhancing domestic production of building materials for mass housing development in Nigeria.

13. Mabogunje, A.L. and Harday, J.E. (1988). Shelter provision in developing countries. The Gresham press.

14. Maurice Umeakuka (2004). Principles and techniques of town and country planning. Springfield Publishers Ltd Owerri.National Housing Policy and program]Nigeria (2011).www.socialhousingnigeria.com/documentation.

NEEDS 2: Housing sector vision transformation agenda: (2011-2015).

15. Oberai, A.S. (1992). Population growth employment and Poverty in third world mega cities dossiers, No 131. Megasoft Publishers Owerri.

16. Okeke, M.I. (1983). Issues in Urbanization and urban administration in Nigeria. Pages 76-67. Supreme Publishers Owerri. 